\title{
Essay
}

\section{Law, Literature, and the Problems}

\section{of Interdisciplinarity}

\author{
Jane B. Baron ${ }^{\dagger}$
}

There is probably someone somewhere who would be willing to say that law is just rules and the techniques of rule manipulation, but in the academy, if not outside of it, this view has long been out of fashion. ${ }^{1}$ Today, a description of law as "a dazzlingly complex array of social, cultural, linguistic, and normative practices" ${ }^{2}$ presents itself not as a revolutionary insight but as a form of common sense. Part of what has educated us to understand law as a phenomenon richer than the sum of its rules is the teachings of the various "law ands" that have grown up over the years-law and economics, law and history, law and society, and the like. In methodologically diverse ways, "law and" scholarship has consistently encouraged consideration of law's dependence on and connection to other

† Professor of Law, Temple University School of Law. I thank Richard Baron, Julia Epstein, and Rick Greenstein for helpful comments on earlier drafts of this Essay. I thank Leonore Carpenter for excellent research assistance. I am especially grateful to Zachary Baron and Ruth Baron, who provided encouragement and advice at key moments in the development of this Essay.

This Essay originated in a talk I gave at a colloquium on law and literature held at University College London in June 1998. I thank Michael Freeman and Andrew Lewis for inviting me to participate in that conference.

1. Judge Posner assured us over a decade ago that the law had declined as an autonomous discipline. See Richard A. Posner, The Decline of Law as an Autonomous Discipline: 1962-1987, 100 HARV. L. REV. 761 (1987). Even those such as Judge Edwards, who have criticized legal scholarship for being insufficiently "practical," have conceded that "abstract theory" and various "law and" movements all "have the potential to serve important educational functions and, therefore, should have a permanent home in the law schools." Harry T. Edwards, The Growing Disjunction Between Legal Education and the Legal Profession, 91 MiCH. L. REV. 34, 34-35 (1992).

2. Janet E. Halley, Notes from the Editorial Advisory Board, 10 YALE J.L. \& HUMAN. 389, 391 (1998). 
disciplines. "In spite of sharp differences among ['law and'] schools," two commentators recently observed, "all concur that the legal world is not to be understood on its own terms, but requires the application of some method or substance provided by other disciplines." 3

One of the other disciplines that has been offered to provide law with the necessary understanding is literature. "Law and literature" may not be the oldest "law and" ${ }^{4}$ or the most influential, ${ }^{5}$ but neither has it played the shy wallflower at the "law and" dance. Law review symposia, ${ }^{6}$ books, ${ }^{7}$ and conferences ${ }^{8}$ have all explored the ways in which law can be connected to, and improved by, literature. Literature, it is said, sheds light on law's gaps, rhetoric, and moral stance. It elucidates law's limits and highlight law's exclusions. Interpretive methods conventionally applied to fictional texts can be applied productively to legal texts, and narrative techniques that draw readers into novels and plays can be employed in the service of legal arguments.

These are provocative and occasionally startling claims, but it is not clear whether those outside the law-and-literature community are truly persuaded. My principal argument in this Essay is that the law-andliterature movement has failed to generate the excitement that it is capable

. 3. Marc Galanter \& Mark Alan Edwards, Introduction: The Path of the Law Ands, 1997 Wis. L. REV. $375,376$.

4. Galanter and Edwards assert that "[1]aw and society and law and economics are the oldest and most institutionalized of the[] law ands." Id. at 376-77 (footnotes omitted). Of course, a great deal depends on how one characterizes the history of the law-and-literature movement. Arguably, it originated in 1908, with the publication of John H. Wigmore, A List of Legal Novels, 2 ILL. L. REV. 574 (1908). The contemporary law-and-literature movement is often traced to the more recent publication of JAMES BOYD WHITE, THE LEGAL IMAGINATION: STUDIES IN THE NATURE OF LEGAL THOUGHT AND EXPRESSION (1973), or to the mid-1980s, when White published two other highly influential books, WHEN WORDS LOSE THEIR MEANING: CONSTTUUTIONS AND RECONSTITUTIONS OF LANGUAGE, CHARACTER, AND COMMUNITY (1984) [hereinafter WHITE, WORDS]; and HERACLES' BOW: ESSAYS ON THE RHETORIC AND POETICS OF THE LAW (1985) [hereinafter WHITE, HERACLES' BOW]. For a somewhat idiosyncratic but very thorough account of the movement's history, see Michael Pantazakos, Ad Humanitatem Pertinent: A Personal Reflection on the History and Purpose of the Law and Literature Movement, 7 CARDOZO STUD. L. \& LITERATURE 31 (1995).

5. That distinction is almost always accorded to law and economics. See, e.g., Galanter \& Edwards, supra note 3, at 378; see also infra note 9 (comparing law and economics to law and literature).

6. See, e.g., Law, Literature, and the Humanities, 63 U. CIN. L. REV. 1 (1994); Symposium, Law and Literature, 39 MERCER L. REV. 739 (1988); Symposium: Law and Literature, 60 TEX. L. REV. 373 (1982).

7. In addition to the works of James Boyd White cited supra note 4, see, for example, IAN WARD, LAW AND LITERATURE: POSSIBILITIES AND PERSPECTIVES (1995); RICHARD WEISBERG, POETHICS AND OTHER STRATEGIES OF LAW AND LITERATURE (1992); and ROBIN WEST, NARRATIVE, AUTHORITY, AND LAW (1993).

8. I am referring here to a law-and-literature colloquium held from June 29 to June 30,1998 at University College London. The conference proceedings will be published as LAW AND LITERATURE (Michael D.A. Freeman \& Andrew D.E. Lewis eds., forthcoming June 1999). See also Daniel J. Kornstein, Introduction to the Volume, 8 CARDOZO STUD. L. \& LITERATURE at ii (Fall/Winter 1996) (describing a conference on law and literature at the University of California at Berkeley's Boalt Hall from September 30 to October 2, 1995). 
of generating within the American legal academy because it has not been sufficiently interdisciplinary, or - to be more precise-it has not been very thoughtful about interdisciplinarity. ${ }^{9}$ At the same time, it has had less influence than it might have had with actual lawyers because it has seemed too interdisciplinary, in the sense of not having a lot to say about the aspect of law with which most lawyers are most concerned: doctrine. There is less of a paradox here than might appear. Law-and-literature scholarship has not questioned what the category "law" consists of and has thus tended inadvertently to reinforce the notion of law as autonomous.

This failing-if it is a failing-is not unusual in "law and" scholarship. Assessments of how legal academics could or should employ learning from other fields typically employ a strategy of compare-and-contrast in which the nature and aims of law are juxtaposed against those of the non-law field to evaluate whether the latter can be used appropriately in the service of the former. ${ }^{10}$ Because the comparisons tend to treat both "law" and the "and" discipline as bounded entities, they do not explicitly consider how the boundaries are drawn. As in the case of law and literature, law tends to be depicted as a more or less empty domain composed mainly of rules. For all of the collective success of the "law ands" in challenging the old-fashioned vision of law as rules, the individual "law ands" have not escaped the spell of Langdellian orthodoxy. More specifically, they have failed to fulfill the potential of interdisciplinary scholarship to examine how we categorize knowledge and why.

Before developing this critique in more detail, I state a separate critique that may be a helpful backdrop. This background critique is that the law-

9. Proving that law and literature has not in fact generated the excitement it might have is difficult, for assessing the impact of ideas is tricky work. In America, we are fond of counting citations, see, e.g., Fred R. Shapiro, The Most-Cited Law Review Articles, 73 CAL. L. REV. 1540 (1985); Fred R. Shapiro, The Most-Cited Law Review Articles Revisited, 71 CHI.-KENT L. REV. 751 (1996), but it is not at all clear that qualitative effects are best evaluated by quantitative measures. Moreover, the pseudo-scientism of citation counting seems inconsistent with a movement committed to nonmechanical, nonreductionist views of law. If (putting aside obvious methodological problems of exactly what we ought to count, how we count it, and so on), we count nonetheless, the results are not very encouraging. To take but one example, in a recent Westlaw search of law reviews and journals, the term 'law and economics' appeared 6675 times; the term 'law and literature' appeared 1655 times. Search of Westlaw JLR database (June 1, 1998).

One of law and literature's principal figures, Robin West, has conceded that law and literature is a "marginal movement" as compared with law and economics. ROBIN WEST, CARING FOR JUSTICE 180 (1997).

10. This technique is described in Jane B. Baron, Interdisciplinary Legal Scholarship as Guilty Pleasure: The Case of Law and Literature, in LAW AND LITERATURE, supra note 8 (manuscript at 2). See generally Charles W. Collier, The Use and Abuse of Humanistic Theory in Law: Reexamining the Assumptions of Interdisciplinary Legal Scholarship, 41 DUKE L.J. 191 (1991) (comparing "the humanities" and law); Martin S. Flaherty, History "Lite" in Modern American Constitutionalism, 95 CoLUM. L. REV. 523 (1995) (comparing history and law); Martha C. Nussbaum, The Use and Abuse of Philosophy in Legal Education, 45 STAN. L. REV. 1627 (1993) (comparing philosophy and law). 
and-literature movement has tended to undermine itself from within. If there is a single movement here, ${ }^{11}$ it is certainly a very fractured one. The concerns of its separate strands are quite disparate. Any theme broad enough to tie all the strands together can be found and stated only at a level of abstraction so high as to threaten banality; such abstraction also undercuts what some within the movement regard as a fundamental commitment to particularity as opposed to grand theory. ${ }^{12}$ This is a movement of many methodologies and conclusions. The multiplicity of approaches and concerns that leads some to see literature as a source of nearly endless possibilities may lead skeptics to dismiss law and literature as an empty vessel, a phrase devoid of content.

The interdisciplinarity critique and the background critique are not necessarily connected. The background critique basically describes a problem of internal fragmentation, of mixed and conflicting messages. The law-and-literature movement could be a great deal more unified and coherent than I argue it actually is and yet still fail to engage meaningfully the question of how and why disciplinary boundaries are being drawn in the way the movement currently draws them.

Still, the critiques may not be wholly unrelated. Each strand of the lawand-literature movement seeks to demonstrate that literature has something to offer law. The less attention that is paid to what law is, for purposes of this comparison, the easier it is to make the case for literature; that is, the less law already includes, the more obvious it is that it requires the supplementation of literature. Explicit recognition that the category "law" might be contingent or created would substantially complicate the argument. It seems no accident that a movement so invested in a vision of law as requiring enhancement from something "outside" should be

11. For arguments that there is a single movement, see, for example, GARY MINDA, POSTMODERN LEGAL MÓOVEMENTS: LAW AND JURISPRUDENCE AT CENTURY'S END 149-66 (1995) (providing a chapter on "the law and literature movement"); WEST, supra note 9, at 179 (" $[\Pi \mathrm{t}$ now makes some sense to speak of the law and literature movement as a recognizable discipline, or subspecialty with its own set of defining questions and tentative lines of analysis within the legal academy."). But see John D. Ayer, "Aliens Are Coming! Drain the Pool," 88 MicH. L. REV. 1584, 1585 (1990) (book review) ("[D]espite the increasing currency of the term [law and literature], no single field of inquiry deserves that name."); Geoffrey P. Miller, $A$ Rhetoric of Law, 52 U. CHI. L. REV. 247, 255 (1985) (book review) (arguing that law and literature lacks the kind of "organized theoretical structure" of law and economics); id. at 255-56 (arguing that because "there is no single well-understood and widely accepted theory of literature," nor "a unifying set of normative values" underlying literary interpretation, there are "serious questions about whether law and literature provides an adequate conceptual foundation to support a coherent body of scholarship"); cf. Thomas Morawetz, Ethics and Style: The Lessons of Literature for Law, 45 STAN. L. REV. 497, 499 (1993) (book review) (suggesting that some scholars wishing to counteract the perception that "the discipline of law and literature is actually the intersection of several distinct and barely overlapping concerns" have sought "to validate the field by identifying a significant core").

12. See, e.g., Judith Resnik, On the Margin: Humanities and Law, 10 YALE J.L. \& HUMaN. 413, 415-17 (1998). 
somewhat careless in its consideration of the boundaries of "law" as a discipline. Both critiques, then, point to a single problem: By treating law's boundaries as both necessary and natural, the law-and-literature movement seems to beg questions it is ostensibly committed to answering, such as whether it makes sense to use the "outside" discipline of literature as a tool to examine what is or could be "inside" law-and, more importantly, how we define what is "internal" and "external" to law as a discipline.

\section{THE ELUSIVE CONNECTION BETWEEN LITERATURE AND LAW}

Unlike college courses, in which professors tend to assign multiple books and have a supplemental list of "suggested" readings to boot, in many law school courses, especially in the first year, only one book is assigned. When I entered law school, I was shocked to learn that the sole book consisted mainly of cases. One learned law, it seemed, by reading law. Only law. One did not read about law. One read the law itself. No more, apparently, was needed.

From the perspective of at least some within the law-and-literature movement, this "only law" approach is misguided. The movement's proponents (whom I shall call hereinafter "law-and-lits") argue that law students, legal academics, and even practicing lawyers should also read literature. But for what purpose should they read literature? What is it that literature can add? Unfortunately, there is no consensus on the answer to this question. Rather, the movement divides into three separate strands. ${ }^{13}$

\section{A. Divisions Within Law and Literature: Three Strands}

Some law-and-lits, whom I shall call "humanist" law-and-lits, argue that lawyers should read literature. Here are some typical claims:

[L]iterary works typically invite their readers to put themselves in the place of people of many different kinds and to take on their experiences.... [T] hey promote identification and sympathy .... ... One may be told many things about people in one's own society and yet keep that knowledge at a distance. Literary works that promote identification and emotional reaction cut through

13. Any characterization of the movement's divisions is to some extent arbitrary. For a slightly different description of the "genres" of law and literature, see Guyora Binder, The Lawas-Literature Trope, in LAW AND LITERATURE, supra note 8 (manuscript at 7). As I will argue, a more conventional approach divides the movement into "law in literature" and "law as literature." See infra text accompanying notes 65-67. Several leading law-and-literature scholars organize their discussion around the three strands identified in the text, although they have not used the identical labels. See, e.g., MINDA, supra note 11, at 153; RICHARD A. POSNER, LAW AND LITERATURE 5-6 (rev. ed. 1998); WEST, supra note 9, at 179. 
those self-protective stratagems, requiring us to see and to respond to many things that may be difficult to confront .... ${ }^{14}$

$* * *$

[L]iterature projects the abstract into the concrete. ${ }^{15}$

$* * *$

Literature trains people in the reflection, consciousness, choice, and responsibility that make up the ability to engage in moral decisionmaking. It does so by presenting artificial, but concrete, universes in which premises may be worked out in conditions conducive to empathy but ambiguous enough to allow for the formation of moral judgment. ${ }^{16}$

Notice that while the claims have slightly different emphases, the basic argument is the same: Literature is needed to humanize lawyers. Borrowing from earlier work, ${ }^{17} \mathrm{I}$ will call this the "moral uplift" theme of the law-andliterature movement. It has several components: First, lawyers need to know more about human nature-especially about people different from themselves - than they can learn on their own, and literature can be a source of this knowledge. ${ }^{18}$ Second, lawyers tend to rely excessively on abstract reason over forms of understanding that are emotional, intuitive, and concrete, and literature can help correct this imbalance. ${ }^{19}$ Third, lawyers require training in making moral judgments, and literature can be a part of the necessary moral education. ${ }^{20}$

While humanist law-and-lits argue that lawyers should read literature, others, whom I shall call "hermeneutic" law-and-lits, argue that lawyers

14. MARTHA NUSSBAUM, POETIC JUSTICE: THE LiteraRy IMAGINATION AND PUBLIC LIFE 5-6 (1995).

15. Harvey Couch, III, Law and Literature-A Comment, 17 VAND. L. REv. 911,914 (1964).

16. Linda R. Hirshman, Brontë, Bloom, and Bork: An Essay on the Moral Education of Judges, 137 U. PA. L. REV. 177, 179 (1988).

17. See Jane B. Baron \& Julia Epstein, Language and the Law: Literature, Narrative, and Legal Theory, in THE POLITICS OF LAW 662, 664 (David Kairys ed., 3d ed. 1998).

18. See, e.g., Wigmore, supra note 4, at 579 (1908).

19. See, e.g., WAI CHEE DIMOCK, Residues OF Justice: LITERATURE, LAW, PHILOSOPHY 10 (1996) (noting that literature transposes the "clean abstractions" of law "into the messiness of representation”); Paul Gewirtz, Aeschylus' Law, 101 HARV. L. REv. 1043, 1050 (1988) ("Literature ... nourishes the kinds of human understanding not achievable through reason alone but involving intuition and feeling as well. If ... law engages nonrational elements and requires the most comprehensive kinds of understanding, literature can play an important part in a lawyer's development.").

20. See, e.g., Richard Weisberg, Coming of Age Some More: "Law and Literature" Beyond the Cradle, 13 Nova L. REv. 107, 123-24 (1988) ("Pedagogically, I am convinced that literature is a better medium for lawyers than is, say, moral philosophy, from which to learn about rightness. It delights as it instructs. It places the inquiry on virtue into a dynamic framework and allows the reader to reason inductively from the cases described to her own experience and thoughts."). 
should read literary theory. The latter group seeks to apply to law interpretive methodologies borrowed from literary studies. The reason is simple. To the extent that law is embodied in texts--such as cases, statutes, contracts, orders-those texts must be read and interpreted. ${ }^{21}$ Literary scholars have concerned themselves with problems of interpretation for a very long time, and it seems that theories and methods developed in the context of literary texts could be applied to legal texts as well. ${ }^{22}$ Why, after all, reinvent the interpretation wheel?

Notice that the project of applying to law interpretive theories developed in departments of English or comparative literature does not require that one actually read any poems, novels, or plays-in short, any literature. While a particular interpretive methodology might have been developed in the context, say, of reading Hamlet, what makes it a methodology (as opposed to an interesting way to read Hamlet) is that it can be applied to other texts as well. So one need not read the play, but only the methodology. Hermeneutic law-and-lits thus do not argue that lawyers need to read literature. Indeed, besides looking beyond legal materials to sources from the humanities, the interpretive project of hermeneutic lawand-lit has very little connection to the moral uplift project of humanist lawand-lit. The two strands of law-and-lit are neither reading the same works nor asking the same questions. ${ }^{23}$

Further splintering this already very fractured movement is yet another set of writings that has come to be associated with law and literature: writings taking up the role of narrative or storytelling in law. ${ }^{24}$ These

21. See, e.g., Mark Kingwell, Let's Ask Again: Is Law Like Literature?, 6 YALE J.L. \& HUMAN. 317, 351 (1994) ("Law is utterly like literature because it consists of written texts that are subject to interpretation. To the extent that a general theory of interpretation is valid ... law and literature are two instances of the same human activity: divining meaning from written artifacts."); see also Sanford Levinson, Law as Literature, in INTERPRETING LAW AND LITERATURE: A HERMENEUTIC READER 155, 157 (Sanford Levinson \& Steven Mailloux eds., 1988) ("The disputes currently raging through literary criticism precisely mirror some of the central problems facing anyone who would take law seriously; the basis of this parallelism is the centrality to law of textual analysis."). But see Kingwell, supra, at 351 (suggesting that at the same time "law is utterly unlike literature in that the practices governed by its texts have quite different goals").

22. For example, Kenneth Abraham writes:

The issues that trouble literary theory ... are strikingly similar to those that have troubled thinking about statutory interpretation. Practitioners of both disciplines have debated at length about the nature of the texts with which they are concerned, the relation of the author's intention to the meaning of a text, and the character of the reader's knowledge of a text's meaning.

Kenneth S. Abraham, Statutory Interpretation and Literary Theory: Some Common Concerns of an Unlikely Pair, in INTERPRETING LAW AND LITERATURE, supra note 21, at 116.

23. Robin West has argued that "for many of its most prominent members interest in the nature of interpretation, and a willingness to borrow from literary studies to further that inquiry, are defining, not just incidental, features of the law and literature movement." WEST, supra note 9, at 203. This formulation suggests the movement can be humanist or hermeneutic, but not both.

24. Richard Posner and Robin West both include law and narrative "within" law and literature in their most recent books. See POSNER, supra note 13, at 345-57; WEST, supra note 9, 
scholars, whom I shall call "narrative" law-and-lits, are far less interested in either literary works or interpretive theory than in attending to the stories told within law by clients, by lawyers, by judges, and by doctrine itself. Narrative law-and-lits are interested in those stories not for moral uplift or interpretive insight but rather for evaluating the stories' persuasive impact, ${ }^{25}$ their evidentiary value, ${ }^{26}$ and their epistemological implications. ${ }^{27}$ Again, there is little connection between the interests of narrative law-and-lits and those of either humanist or hermeneutic law-and-lits.

\section{B. Divisions Within Each Strand}

Within each strand of law and literature, there are deep problems and divisions. Let us begin with the moral uplift theme of humanist law-and-lit. First, nothing guarantees that reading literature will actually help attain the goals of the moral uplift project. Surely many an insensitive brute has read great books without becoming one whit less insensitive or brutish. And even if it were true that lawyers could learn something from literature about human nature, nonrational understanding, and moral judgment, it is not clear that literature is the only-let alone the best-source of education on these matters. Why not study psychology, cognitive theory, or ethics? Moreover, what do these goals have to do specifically with law, anyway? Surely doctors also need to know every bit as much as lawyers about

at 207-15; see also MINDA, supra note 11, at 153 (including narrative among "the basic forms of jurisprudence" of the law-and-literature movement).

25. See, e.g., Paul Gewirtz, Narrative and Rhetoric in the Law, in LAW's STORIES: NARRATIVE AND RHETORIC IN THE LAW 2, 5 (Peter Brooks \& Paul Gewirtz eds., 1996) ("Storytelling in law is narrative within a culture of argument. Virtually everyone in the legal culture ... is explicitly or implicitly making an argument and trying to persuade. Storytelling is, or is made to function as, argument.") [hereinafter LAW's STORIES]; Gerald López, Lay Lawyering, 32 UCLA L. REV. 1 passim (1984) (describing the role of "stock stories" in both ordinary and legal persuasion).

26. See, e.g., William N. Eskridge, Jr., Gaylegal Narratives, 46 STAN. L. REv. 607, 614 (1994) ("Gaylegal narratives have important informational value."); Martha R. Mahoney, Legal Images of Battered Women: Redefining the Issue of Separation, 90 MrCH. L. REV. 1, 7 (1991) (offering "narratives and poems from the lives of survivors of domestic violence, and a few from the stories of non-survivors," in order "[t]o illustrate the contrast between women's lives and legal and cultural stereotypes"); Ruthann Robson, Beginning from (My) Experience: The Paradoxes of Lesbian/Queer Narrativities, 48 HASTINGS L.J. 1387, 1387 (1997) ("[T]he importance of narrative rests upon the belief that the present legal landscape can be improved if those of us outside the dominant group make public our experiences.").

27. As Eskridge notes:

[H]uman decisionmaking is weblike, in that one value or line of thinking is connected to and reinforced by many other values or lines of thought. The connections and reinforcing features of thought are not systematic, and for that reason they are hard to conceptualize in the abstract. Concrete narratives of actual interactions and histories can illustrate these interconnections, however.

Eskridge, supra note 26, at 617 (footnote omitted); see also Kim Lane Scheppele, Foreword: Telling Stories, 87 MICH. L. REV. 2073, 2088-94 (1989) (suggesting that the existence of multiple plausible stories of a single event raises questions about the "objectivist theory of truth"). 
human nature, the role of the emotions in human thinking, and moral decisionmaking. Indeed, a medicine and literature movement has grown up around just these claims. ${ }^{28}$

Even assuming both that moral uplift is worthwhile and that literature can provide it, there is a question about which books, exactly, should be read. The most salient version of this question concerns the construction of the "canon." 29 The arguments that the traditional canon is limited are (I hope) too well developed to require recapitulation here. ${ }^{30}$ Suffice it to say that the more the canon excludes the voices of outsiders and women, the less enriching and emancipatory the cross of literature with law is likely to be. $^{31}$

Yet there is another problem of selection, even within the existing canon. Why read one book rather than another? The original humanist lawand-lits at least could narrow the field somewhat, as they argued that lawyers should read books that were about law in some sense-containing a trial scene, portraying "typical traits of a lawyer or judge," delineating the prosecution and punishment of a crime, or having a plot into which some point of law entered. ${ }^{32}$ But with limited exceptions, ${ }^{33}$ contemporary humanist law-and-lits do not limit their reading to works touching law. Beatrix Potter's The Tale of Peter Rabbit, ${ }^{34}$ James Fenimore Cooper's The Deerslayer, ${ }^{35}$ Toni Morrison's Beloved, ${ }^{36}$ and Charlotte Brontë's Jane $E y r e^{37}$ have all been enlisted in aid of the moral uplift project. Indeed, what

28. See, e.g., HOWARD BRODY, STORIES OF SICKNESS (1987); JULIA EPSTEIN, AlTERED CONDITIONS: DisEASE, MEDICINE, AND STORYTELling (1995); KATHRYN MONTGOMERY HUNTER, DOCTORS' STORIES: THE NARRATIVE STRUCTURE OF MEDICAL KNOWLEDGE (1991).

29. On "canonicity" within law and literature generally, see J.M. Balkin \& Sanford Levinson, The Canons of Constitutional Law, 111 HARV. L. REV. 963, 968-69 (1998).

30. See generally, e.g., Richard Delgado \& Jean Stefancic, Norms and Narratives: Can Judges Avoid Serious Moral Error?, 69 TEx. L. REv. 1929 (1991) (discussing outsiders and the canon); Carolyn Heilbrun \& Judith Resnik, Convergences: Law, Literature, and Feminism, 99 YALE L.J. 1913 (1990) (discussing women and the canon); Judith Resnik, Changing the Topic, 8 CARDOZO STUD. L. \& LITERATURE 339 (1996) (same).

31. Robin West discusses the effects on law of the limitations of the literary canon:

The literary canon will reflect the moral sensibilities of the same elite whose interests are reflected and served by law. Those moral sensibilities might, indeed, be in rebellion against the legal and political order of the day. But they are nevertheless the sensibilities of elites. The voices, experiences, and perspectives of outsiders will only rarely infiltrate, and a form of critique that depends upon the canon for its critical insights will reflect that limitation.

WEST, supra note 9, at 195. For a defense of the traditional canon, see WEISBERG, supra note 7, at 117-23.

32. These were Wigmore's initial subdivisions of legal novels. See Wigmore, supra note 4, at 574. For a slight restatement of these categories, see Richard H. Weisberg, Wigmore's "Legal Novels" Revisited: New Resources for the Expansive Lawyer, 71 NW. L. REV. 17, 18 (1976).

33. See WEISBERG, supra note 7, at 34 (noting that Wigmore "was right to focus on books that had law as their central theme").

34. See WARD, supra note 7, at 100.

35. See DIMOCK, supra note 19 , at 27-56.

36. See WEST, supra note 9, at 197-98.

37. See Hirshman, supra note 16, at 209-17. 
work of literature could not be? Does not any work of literature-old or new, mainstream or alternative-have something to teach about human nature, the role of the emotions and intuition, and moral decisionmaking? $?^{3 \mathrm{~s}}$

The problem of apparently random selection is aggravated by the diversity of styles and attitudes with which humanist law-and-lits read. Perhaps this diversity was inevitable, as legal scholars seem to have turned to literary studies just when there was the least consensus within the latter field about how to read. ${ }^{39}$ Whatever the reason, the result is unquestionable: One humanist law-and-lit might read in a New Critical style, ${ }^{40}$ while another may be concerned with historical context, ${ }^{41}$ and still another might be an intentionalist. ${ }^{42}$

Ironically, for all the apparent diversity, there is a certain sameness to the structure of humanist law-and-lit writing. Such scholarship often seems to oscillate between the poles of high generality and exacting specificity, offering large and abstract claims, and supporting them with closely detailed readings of selected texts. The typical essay ${ }^{43}$ begins with an assertion about the connection between literature and law-a statement, usually, of what literature can teach lawyers. ${ }^{44}$ It then proffers a work of

38. Judge Posner has explicitly repudiated this position, arguing that only literature that has withstood the test of time and survived in the literary "marketplace" is capable of teaching valuable lessons. POSNER, supra note 13, at 11-23.

39. Robert Weisberg notes:

[The] turn to literature for renewal is ironic, since... it is literature itself whose internal troubles seem to best reflect the various types of alienation, malaise, and disbelief which are said to distress modern culture. In that regard, it may be more appropriate to look to literature as a model of postmodernist confusion than as a cure for it.

Robert Weisberg, Reading Poethics, 15 CARDOZO L. REv. 1103, 1103 (1994) (book review).

40. See, e.g., Jeffrey Malkin, Law on a Darkling Plain, 101 HARV. L. REV. 702, 711 (1988) (book review) (asserting that James Boyd White's readings reflect a "New Critical" approach, along with a "modified version of reader response theory").

41. See, e.g., Stanley Fish, Don't Know Much About the Middle Ages: Posner on Law and Literature, 97 YALE L.J. 777, 781-82 (1988) (arguing that Posner "egregiously lacks" a sense of history); Mark V. Tushnet, Translation as Argument, 32 WM. \& MARY L. REV. 105, 113-18 (1990) (book review) (criticizing White for ignoring history).

42. See, e.g., Richard A. Posner, Law and Literature: A Relation Reargued, 72 VA. L. REV. 1351,1361 (1986) ("I believe it perfectly consistent for someone to be an 'intentionalist' when it comes to reading statutes and the Constitution and a 'New Critic' when it comes to reading works of literature ...."). But see WEISBERG, supra note 7, at 197 (asserting that Posner is actually an intentionalist, not the New Critic he claims to be). For Posner's most recent views, see POSNER, supra note 13, at 209-54.

43. Almost any of the works previously cited in this Essay could also be cited in this footnote. For a collection of essays reflecting this typical structure, see LAW AND LITERATURE PERSPECTIVES (Bruce L. Rockwood ed., 1996).

44. See, e.g., Paul J. Heald, Medea and the Un-Man, in LITERATURE AND LEGAL PROBLEM SOLVING: LAW AND LITERATURE AS ETHICAL Discourse 55, 57 (Paul J. Heald ed., 1998) (stating that "[f]iction comprises a huge repository of stories about who should live and who should die, what is good and what is evil, what is heinous and what is merely pathetic," and therefore judges can look to literature to "give content to the term "heinous"" for purposes of determining who should receive the death penalty under Maynard v. Cartwright, 486 U.S. 356 (1988)). 
literature that will demonstrate the connection and teach the lesson. ${ }^{45}$ There follows a summary of the plot and, where appropriate, the characters. ${ }^{46}$ Then comes the most difficult step, as the message of the literary work for law is drawn out. ${ }^{47}$ Here we find a close examination of a particular passage or turn of the plot and what that passage or turn "means." 48 From the particular, we move back to the general, where-to no one's surprise-we find that the promised connection has been made, the lesson taught. ${ }^{49}$

Is it true that "Franz Kafka's fictional works on the nature of law dramatize a dark underside of [Richard] Posner's argument that the fact of consent morally legitimates our legal, social, and personal worlds" ? $?^{50}$ Is it correct that, in Song of Myself, Walt Whitman "claims that the light of the poetic imagination is a crucial agent of democratic equality for ... excluded people, since only that imagination will get the facts of their lives right" ?1 $^{5}$ Is "the lesson of The Scarlet Letter" that "once the seriousness of the decision to bear or beget a child is recognized, excluding women from citizenship by denying them this freedom is wrong" ?52 Is Aeschylus' Oresteia trilogy "fundamentally a story about the emergence of law" ?3

45. See, e.g., Judy M. Cornett, The Treachery of Perception: Evidence and Experience in Clarissa, 63 U. CIN. L. REv. 165, 168-69 (1994) (offering Samuel Richardson's Clarissa to expose "the fundamental assumptions underlying the Lockean framework of eighteenth-century evidence law"); Heald, supra note 44, at 58-60 (offering Dante's Inferno, C.S. Lewis's Perelandra, and Euripides' Medea on the issue of "heinousness"); see also Margaret J. Fried \& Lawrence A. Frolik, The Limits of Law: Litigation, Lawyers and the Search for Justice in Russell Banks' The Sweet Hereafter, 7 CARDOZo STUD. L. \& LITERATURE 1 (1995) ("[The Sweet Hereafter] presents a rather pessimistic account of our system of law, in particular the tort law system, and questions the law's ability to determine the truth and render justice.").

46. See, e.g., Cornett, supra note 45, at 177-90 (summarizing plot developments in Clarissa); Fried \& Frolik, supra note 45, at 3-17 (summarizing the narratives of the individual characters in The Sweet Hereafter); Heald, supra note 44, at 58-63 (summarizing stories of murder told in various literary works).

47. See, e.g., Heald, supra note 44, at 63 ("Dante and Lewis are clearly attempting to describe a different type of murderer than is Euripides."). But see id. at 63-65 (recognizing "potential difficulties with using literature to answer the question" of what kind of murderer should receive the death penalty).

48. See, e.g., Fried \& Frolik, supra note 45, at 17-18 (examining the demolition derby scene at the conclusion of The Sweet Hereafter); Heald, supra note 44, at 61 (examining a speech by Jason in Medea).

49. See, e.g., Cornett, supra note 45, at 191-92 ("The eighteenth-century law of evidence presupposed human depravity .... Clarissa's story exposes ... the inadequacy of the Lockean model of cognitive self-sufficiency for knowers who are innocent and powerless."); Fried \& Frolik, supra note 45, at 18 ("Through the microcosm of [the fictional town of] Sam Dent, Banks reveals the fundamental belief that justice means the punishment of the guilty."); Heald, supra note 44, at 72 (arguing that "a reading of Euripides, Dante, and Lewis" supports the "specific" thesis that "Medea's crimes are not heinous for the purposes of Maynard, but that the Un-man's are" and that "[a] yet broader suggestion might be made that Euripides, Dante, and Lewis improve the quality of the heinousness debate, raising the ethical level of the discussion irrespective of what standard the state eventually decides to implement").

50. WEST, supra note 7, at 29.

51. NUSSBAUM, supra note 14, at 119.

52. Hirshman, supra note 16, at 223.

53. Gewirtz, supra note 19, at 1044 . 
These assertions may or may not be true. Certainly they are not selfevidently true. The problem is not that lawyers and legal scholars are incapable of informed, sensitive readings of important literary works; interpretation of literary works need not be the exclusive province of literary scholars. But literary scholars rarely agree among themselves on anything like a single correct interpretation of an important creative work. ${ }^{54}$ I have presented the conclusory interpretations above in a rather harsh, decontextualized light, but a disconcerting aspect of the moral uplift project is that it almost demands that works of literature be read, like fables, for their "message." The certainty with which legal scholars assert what are actually quite contestable readings is, thus, understandable, but still incongruous. Not only do the conclusions impart an air of closure that seems inappropriate to the complexity of the works at issue, but the certainty with which they are proposed seems at odds with the inquiring spirit alleged to animate the turn to literature in the first place.

And just to ice the cake, humanist law-and-lits cannot agree over the substance of these readings. While humanist law-and-lits agree that it is important to look at law through the lens of literature, this turns out to be a very superficial commonality, for what they see through the lens is almost unrecognizably different. The individual theorists often disagree-and vehemently-over what to make of what they have read. For example, Robin West and Richard Posner diverge dramatically over the implications of the works of Franz Kafka on the core tenets of law and economics. ${ }^{55}$ Posner also strongly disagrees with Richard Weisberg's readings of Melville's Billy Budd and Dostoevsky's The Brothers Karamazov. ${ }^{56}$ Weisberg in turn challenges Posner's readings of these works, as well as Posner's interpretation of The Merchant of Venice. ${ }^{57}$ Weisberg also extensively critiques James Boyd White's readings of various literary works. ${ }^{58}$ And Robin West has criticized the projects of both White and Weisberg. ${ }^{59}$

I have dwelt at length on the internal divisions among humanist lawand-lits, but only because their difficulties are illustrative of the deeper problem of holding each strand in this movement together. Among hermeneutic law-and-lits, there are also deep rifts. Debate over interpretive

54. Indeed, it has been argued that the goal of literary as opposed to legal scholarship is to "open up" texts rather than to discover a single meaning. See Gerald Wetlaufer, Rhetoric and Its Denial in Legal Discourse, 76 VA. L. REV. 1545, 1573 (1990) ("While scholars in law and literature share an interest in the interpretation of texts, they are likely to have quite different ideas about what that might entail. Literary scholarship is a realm in which the illumination of a text does not involve the identification of its one true meaning.").

55. See POSNER, supra note 13, at 182-205 (summarizing the debate).

56. See id. at 165-79.

57. See WEISBERG, supra note 7, at 196-210.

58. See id. at 224-50.

59. See WEST, supra note 9, at 180-88 (criticizing White), 190-200 (criticizing Weisberg). 
methodologies has mushroomed within English and comparative literature departments over the past ten to twenty years, so it is not surprising that hermeneutic law-and-lits are easily as divided among themselves as humanist law-and-lits. The preeminent issue for hermeneutic law-and-lits has been power: Who or what "controls" the meaning of a text-the author, the reader, the words of the text, conventions of reading? Beyond a tendency to approach this issue by focusing on a single legal text, the U.S. Constitution, the hermeneutic law-and-lits have found little on which to agree. Intentionalists clash with deconstructionists on one side and textualists on the other. ${ }^{60}$ Meanwhile, other scholars enter the argument only to assert that nothing at all turns on the outcome, ${ }^{61}$ while still others have made the opposite point: that too much turns on the outcome of real legal cases to make the analogy to literary interpretation apt. ${ }^{62}$

Finally, law-and-narrative scholarship itself has three strands, one focusing on the strategic use of storytelling as a persuasive technique, the second focusing on the evidentiary use of storytelling to supply information about how the law actually functions in real-world settings, and the third focusing on how multiple inconsistent stories might accurately be told of the same event and raising questions about the sustainability of the legal vision of truth as univocal. ${ }^{63}$ As is true within both humanist and hermeneutic law-and-lit, the three strands of law and narrative scholarship often conflict with one another. Evidentiary storytelling, for example, is meant to show something true, but previously unnoticed, about the world, whereas the telling of multiple stories is meant to challenge the idea of objective truth. $^{64}$

\section{Is There a "Movement" Here?}

Much of the writing about law and literature has more or less taken for granted that there is a law-and-literature movement and progressed quickly into discussions of its basic divisions into "law in literature" and "law as

60. A sampling of the various approaches can be found in INTERPRETING LAW AND LITERATURE, supra note 21. (1987).

61. See, e.g., Stanley Fish, Dennis Martinez and the Uses of Theory, 96 YALE L.J. 1773

62. This observation was first made by Robert Cover in Violence and the Word, 95 YALE L.J. 1601 (1986), and was then reiterated by Robin West. See WEST, supra note 7, at 89-176. In more recent work, West has admitted that these dissents "did not ring loudly." WEST, supra note 9, at 203.

63. These strands are described at somewhat greater length in Baron \& Epstein, supra note 17 , at $668-70$.

64. For further development of this point, see Jane B. Baron \& Julia Epstein, Is Law Narrative?, 45 BUFF. L. REV. 141 (1997). 
literature." 65 To be sure, "law and literature" classes are being taught at a not insignificant number of American law schools, ${ }^{66}$ and a reasonably high number of scholarly works have focused on various aspects of law and literature. ${ }^{67}$ But mere interest in law and literature does not a movement make.

Does it matter that the strands of the law-and-literature movement are all to some extent internally divided and that the three strands connect to each other so loosely? Certainly it has been argued that the "interdisciplinary eclecticism" ${ }^{68}$ of law-and-humanities scholarship is itself a good, fostering creativity and experimentation. Yet the less attractive possibility is that what some see as creative diversity others will see as methodological confusion. In the world of law and literature, as we have seen, it is not uncommon for different scholars to find very different messages in the works they read. Again, perhaps it is good that there is such sharp divergence among scholars, for it suggests that literature is a rich and complex source, capable of multiple interpretations and thereby provocative of dialogue. But, to put things in the worst possible light, perhaps the divergence reveals that legal scholars can find just about anything in literature-hope, despair, community, alienation-and that what they do find is more or less a function of what they were looking for initially.

Some will argue that, to this point, I have been highly unfair to the lawand-literature movement, emphasizing its worst problems and using as examples its most exaggerated claims. I have, indeed, given scant attention to works that, without making particularly grand assertions about the power of literature to transform law, nonetheless use literary techniques to analyze, for example, the generally unacknowledged rhetorical structure of judicial opinions. ${ }^{69}$ Nor have I described articles that employ fictional works (or characters from those works) as heuristic types that provide rich, nuanced, and yet shorthand descriptions of professional identities and

65. The former is generally the focus of what I have called the humanist law-and-lits, while the latter is generally the focus of the hermeneutic law-and-lits. The distinction, however, has been widely criticized. See, e.g., Ayer, supra note 11, at 1585 (noting four "disparate topics" that pass for "law and literature"); Morawetz, supra note 11, at 497-99 (discussing four strands of law and literature); see also supra note 13 (arguing that any description of the divisions within law and literature will be to a certain extent arbitrary).

66. See Elizabeth Villiers Gemmette, Law and Literature: An Unnecessarily Suspect Class in the Liberal Arts Component of the Law School Curriculum, 23 VALPARAISO U. L. REV. 267 (1989) (analyzing the place of law and literature within the law school curriculum); Elizabeth Villiers Gemmette, Law and Literature: Joining the Class Action, 29 VALPARAISO U. L. REV. 665 (1995) (surveying law-and-literature courses in United States law schools).

67. See, e.g., INTERPRETING LAW AND LITERATURE, supra note 21; POSNER, supra note 13; WARD, supra note 7; WEISBERG, supra note 7; WEST, supra note 7.

68. Austin Sarat, Traditions and Trajectories in Law and Humanities Scholarship, 10 YALE J.L. \& HUMAN. 101, 103 (1998).

69. See, e.g., Robert A. Ferguson, The Judicial Opinion as a Literary Genre, 2 YALE J.L. \& Human. 201 (1990); Sanford Levinson, The Rhetoric of the Judicial Opinion, in LAw's STORIES, supra note 25 , at 187 . 
dilemmas. ${ }^{70} \mathrm{I}$ have said little about creative and enlightening juxtapositions of literary and legal treatment of concepts such as a "person" 71 or "property." 72 Nor have I touched on the connections between law and literature and other movements such as law and feminism. ${ }^{73}$

I have not, in short, covered every aspect of work in law and literature, nor have I presented the movement in its best possible light. ${ }^{74}$ These choices have been deliberate. My project here is not to praise law and literature, but to try to explain why efforts to use literature in legal contexts-many of which are praiseworthy indeed-have had, relatively speaking, so little impact. For this project, it is important to look at lawand-literature scholarship with a cynic's eye. Taking a cynical view of the divergent readings that seem possible-all held seriously and confidently, all tending in different directions-it is not surprising that many remain skeptical about literature's potential as a source of enlightenment for law.

\section{LAW, LITERATURE, AND INTERDISCIPLINARITY}

\section{A. The Legal Academy, Interdisciplinarity, and Law and Literature}

At this point it is probably worth reflecting for a moment about style and tone. Having argued that there may not actually be a law-and-literature movement, it seems odd to make claims about what "law and literature" or "law-and-literature scholarship" has or has not done. The obvious alternative is to speak very particularly of individual authors, focusing on the nuances of each's work. The risk here, of course, is descent into the ad hominem-a risk that, alas, has all too often been realized. ${ }^{75}$ Since I do not wish to write in these terms, I will assume that, notwithstanding

70. See, e.g., William Simon, Ethics, Professionalism, and Meaningful Work, 26 HoFsTRA L. REV. 445 (1997) (using portrayals of lawyers in works by, inter alia, Dickens, Dostoevsky, and Kafka to illustrate dilemmas of professional alienation); see also Rob Atkinson, How the Butler Was Made To Do It: The Perverted Professionalism of The Remains of the Day, 105 YALE L.J. 177 (1995) (using Ishiguro's novel as a "text" on professionalism).

71. See, e.g., Barbara Johnson, Anthropomorphism in Lyric and Law, 10 YALE J.L. \& HUMAN. 549, 550 (1998) (dealing with the concept of a "person").

72. See, e.g., Roberta Kevelson, Property as Rhetoric in Law, 4 CARDozo STUD. L. \& LITERATURE 189 (1992) (dealing with the concept of "property").

73. For an overview, see the essays collected in BEYOND PORTIA: WOMEN, LAW, AND LITERATURE IN THE UNITED STATES (Jacqueline St. Joan \& Annette Bennington McElhiney eds., 1997). See also Judith Resnik, Singular and Aggregate Voices: Audience and Authority in Law \& Literature and in Law \& Feminism, in LAW AND LITERATURE, supra note 8 (manuscript at 7-30) (assessing the implications for the law-and-literature movement of the narrative techniques employed by gender task forces).

74. While I am confessing, I suppose I should note that I myself have used personal narrative in some of my own scholarly work and so may be counted a part of the very movement I here critique. See Jane B. Baron, Intention, Interpretation, and Stories, 42 DUKE L.J. 630, 661-64 (1992) (telling the story of my father's will).

75. To provide examples here would simply reenact the wrong of such attacks. 
divergences among the humanist, hermeneutic, and narrative strands of law and literature, it nonetheless makes sense to think about something that might be called the "enterprise" of law and literature. This enterprise, most broadly conceived, is about assessing the connections between two fields often thought to be different.

There is a kind of standard story about this enterprise. ${ }^{76}$ Until the Civil War, this story goes, the man of law in the United States (there were, of course, no women lawyers) was also a man of letters. But by about 1870 , when Christopher Columbus Langdell became dean of Harvard Law School, law began to be conceptualized as a science rather than an art, a specialized professional discipline characterized by its own logic, methodology, and subject matter. Once law became an independent field, literature was no longer a part of legal education, nor was it a part of lawyers' everyday competence. Putting this point in a slightly different way, there was no "and" to law in its Langdellian form; law was autonomous. Indeed, this lack of an "and" was what made law law."

This vision of law as autonomous has been resisted almost from the start. Early in the twentieth century, legal "realists" began to question whether legal principles alone could dictate or explain outcomes, while legal "progressives" argued that law was not an autonomous system of norms, but rather "an instrument for the conscious pursuit of social welfare," requiring lawyers to understand not just legal but also social facts and to act as social engineers. ${ }^{78}$ Despite this resistance, however, the notion of law as an independent, self-sustaining field remained powerful.

Oddly, one marker of this power is the development of various "law ands" that offer other areas of knowledge and alternative methodologies to

76. This story relies heavily on two highly influential books: ROBERT F. FERGUSON, LAW AND LETTERS IN AMERICAN CULTURE (1984); and ROBERT STEVENS, LAW SCHOOL: LEGAL EDUCATION IN AMERICA FROM THE 1850S TO THE 1980S (1983).

I am not a historian, and therefore I cannot directly attest to the accuracy of this story, but I believe it to be true. However this may be, there is no doubting the story's power in structuring accounts of the place of law and literature in the intellectual and social history of the legal profession. See, e.g., Hirshman, supra note 16, at 197-98 (situating the "resurgence of the profession's interest in literary, imaginative representation" in the context of the historical developments described by Ferguson and Stevens); Brook Thomas, Reflections on the Law and Literature Revival, 17 CRIMCAL INQUIRY 510, 513-14 (1991) (explaining that the law-andliterature movement "attempts to reconnect disciplines that have a history of connections"); WEST, supra note 9, at 182-83 (describing some parts of the contemporary law-and-literature movement as attempts to "resurrect for the modern sensibility" a 19th-century ideal of what it means to be a good lawyer).

77. For more on Langdell and the vision of law as autonomous, see W. Burlette Carter, Reconstructing Langdell, 32 GA. L. REV. 1, 4-11 (1997); Thomas C. Grey, Langdell's Orthodoxy, 45 U. PITT. L. REV. 1, 37-38 (1983) [hereinafter Grey, Langdell's Orthodoxy]; Thomas C. Grey, Modern American Legal Thought, 106 YALE L.J. 493, 495-96 (1996) (book review) [hereinafter Grey, Modern American Legal Thought].

78. Grey, Modern American Legal Thought, supra note 77, at 498-99. On legal realism, see NEIL DUXBURY, PATTERNS OF AMERICAN JURISPRUDENCE 65-159 (1995); LAURA KALMAN, LEGAL REALISM AT YALE 1927-1960 (1986). 
supplement, enrich, or correct law. In this conceptual scheme, literature is one of many rich sources that provide information about and perspective on law, and law and literature is the interdisciplinary endeavor by which these two particular fields are used to enhance each other. That is, law and literature is but one of several "interdisciplines" involving law. And so it would seem that the law-and-literature enterprise offers the opportunity to explore questions about the definition of disciplinary boundaries and, indeed, about the notion of interdisciplinarity generally.

To examine law and literature as an instance of interdisciplinarity, it is helpful to focus less on particular substantive claims about the ways in which law is the same as or different from literature, and more on the way in which claims about law and literature are structured. Law-and-literature scholars repeatedly ask questions in something like the following form: "How is law like (or unlike) literature?" or "What is it that literature has to say to law?" 79 The answers, predictably, tend to follow the form of the questions, asserting that "literature is (not) like law in these (enumerated) ways"; or that "literature is (not) useful to law in these (enumerated) senses"; or that "(un)like law, literature ...." ${ }^{80}$ Both the questions and the answers seem to posit that law and literature are separate disciplinary domains that either do or do not meaningfully connect to one another. That is, there is "literature" and there is "law," and they are, apparently, separate realms that can be like or unlike, useful or not useful to one another.

At the same time, however, an important component of law-andliterature scholarship is devoted to establishing whether law and literature are in fact appropriately considered two enterprises (the view, for example, of Richard Posner ${ }^{81}$ ) or one (the view, most notably, of James Boyd

79. See, e.g., Kingwell, supra note 21 (asking in its title what literature contributes to law); James Boyd White, What Can a Lawyer Learn from Literature?, 102 HARV. L. REV. 2014 (1989) (book review) (asking the latter question); see also Abraham, supra note 22, at 125 (comparing literary and statutory interpretation); Gewirtz, supra note 19, at 1043 ("I am ... interested ... in efforts to augment the 'law and literature' movement with work that explores the relevance to law of literature itself ...."); Paul J. Heald, Law and Literature as Ethical Discourse, in LTTERATURE AND LEGAL PROBLEM SOLVING, supra note 44, at 4 ("The essential connection of law to the question of how we should live ... makes the study of literature relevant to law.").

80. See, e.g., Michael J. Kaufman, The Value of Friendship in Law and Literature, 60 FORDHAM L. REV. 645, 704 (1992) (" $[\mathrm{L}] \mathrm{aw}$, like literature, is only the play of differences ...."); Weisberg, supra note 39, at 1106 ("Law seeks to close texts ... while literary scholarship sets out ... to open them up."); Gretchen A. Craft, Note, The Persistence of Dread in Law and Literature, 102 YALE L.J. 521, 522 (1992) ("Literature captures and suspends fear, allowing readers to contemplate perils of an arbitrary fate. Law, on the other hand, is an antidote to fate."); John Fischer, Note, Reading Literature/Reading Law: Is There a Literary Jurisprudence?, 72 TEX. L. REV. 135, 159 (1993) ("Unlike literature ... the law inevitably speaks in the language of power and coercion ....").

81. As Posner notes:

Law and literature have significant commonalities and intersections, but the differences are as important. Law is a system of social control as well as a body of texts, and its 
White ${ }^{82}$ ). This debate thus calls into question what much ordinary law-andliterature scholarship assumes. One would think, then, that as a whole the law-and-literature enterprise would be very thoughtful about the delineation-or dare I say, the construction - of disciplinary boundaries.

Ongoing debates arising in other "law ands" in the United States would make such thoughtfulness very timely. These debates tend to be structured by the same compare-and-contrast strategy used to assess law's (un)likeness to literature. The nature and aims of "law" are juxtaposed against those of, say, philosophy or history ${ }^{83}$ to ascertain whether the methods of the latter can be used in the service of law. ${ }^{84}$ So, for example, it has been asserted that historians "favor context, change, and explanation," while authors of lawyers' legal history "value text, continuity, and prescription." ${ }^{85}$ Similarly, it has been argued that, within philosophy, "authority" is "earned" by having "garner[ed] support through centuries of reasoned debate and intellectual assessment," while legal authority is "institutional," resting on "the mere fact that a case has been decided one way rather than another, or that a judge has made a particular pronouncement." 86 The comparisons depict each of the contrasted disciplines as separate, having its own "internal" conventions and

operation is illuminated by the social sciences and judged by ethical criteria. Literature is an art, and the best methods for interpreting and evaluating it are aesthetic.

See POSNER, supra note 13, at 7; see also Richard A. Posner, Law and Literature: A Relationship Reargued, 72 VA. L. REv. 1351, 1392 (1986) ("I myself do not think law is a humanity. It is a technique of government.").

82. See WHITE, HERACLES" Bow, supra note 4, at xi ("[F]or me the activity of law is at heart a literary one ...."); JAMES BOYD WHITE, JUSTICE AS TRANSLATION: AN ESSAY IN CULTURAL AND LEGAL CRITICISM 91 (1990) ("The law is ... at its heart an interpretive and compositionaland in this sense a radically literary-activity.") [hereinafter WHITE, JUSTICE AS TRANSLATION]. Similarly, White has noted:

The heart of literary discourse is self-consciousness of the language itself: of its social and cultural implications, of its over-commitment and dead spots.... [L]iterary texts are characteristically marked by a tension between languages (such as that between the concrete and the abstract); the effect is to qualify each language while using it. The art-it is the art of "integration"- lies in writing two ways at once. In this respect law is naturally literary, for the legal case as we normally think of it can be neither an exercise in abstract analysis nor the presentation of mere particulars, but requires the interaction of both modes of discourse; similarly, it requires attention to the case not from one point of view or another-the plaintiff's or the defendant's-but from both at once.

WHTTE, JUSTICE AS TRANSLATION, supra, at 40.

83. See, e.g., Flaherty, supra note 10 (history); Laura Kalman, Border Patrol: Reflections on the Turn to History in Legal Scholarship, 66 FORDHAM L. REV. 87 (1997) (history); Brian Leiter, Intellectual Voyeurism in Legal Scholarship, 4 YALE J.L. \& HUMAN. 79 (1992) (philosophy); Nussbaum, supra note 10 (philosophy); see also Annelise Riles, Representing In-Between: Law, Anthropology, and the Rhetoric of Interdisciplinarity, 1994 U. ILL. L. REV. 597 (anthropology); Mike Townsend, Implications of Foundational Crises in Mathematics: A Case Study in Interdisciplinary Legal Research, 71 WASH. L. REV. 51 (1996) (mathematics).

84. See, e.g., Nussbaum, supra note 10, at 1630-41 (describing how philosophy can be useful in legal education).

85. LAURA Kalman, The Strange CAREer OF LEgal LiberalisM 180 (1996).

86. Collier, supra note 10, at 220. 
objectives, but almost no one is terribly clear about how these boundaries are drawn. ${ }^{57}$ Indeed, the less attention given the boundaries, the better; acknowledging that sometimes lawyers are sensitive to context (even in their use of history) or that some legal authority is respected precisely because its reasoning has stood up over time would undermine substantially the rhetorical force of the comparisons.

Whatever the reason, most assessments of "ands" other than literature assume that disciplines have boundaries and are highly critical of how the boundaries are treated. The debates, most noisily typified by controversy over the use of history by those advocating civic republican interpretations of constitutional theory, ${ }^{88}$ have been characterized by charges that legal scholars "misuse" or "abuse" other disciplines, ${ }^{89}$ that their analyses lack "rigor" or are "sub-standard," "decoration" to lend spurious authority to ideas that should stand, or fall, on their own. ${ }^{91}$ These charges have led in turn to suggestions that interdisciplinarity in law is always merely apparent, ${ }^{92}$ that, conversely, the very idea of a disciplinary perspective or concept has become unintelligible, ${ }^{93}$ and that attempts at interdisciplinarity only create new, unrecognized disciplines. ${ }^{94}$

Echoes of these controversies may occasionally and faintly be heard in writing about law and literature. Here and there one comes across the injunction not to read literature for political or ethical purposes, but rather

87. Those who have explicitly considered what exactly divides legal scholarship from other disciplines have argued that the determining factor is the overwhelming prescriptive nature of legal scholarship. See Edward L. Rubin, Law And and the Methodology of Law, 1997 WIS. L. REV. 521, 542 ("The defining feature of standard legal scholarship is its prescriptive voice; . . it is this feature that distinguishes it from other academic fields."); see also Wetlaufer, supra note 54 , at 1566,1572 ("One could fairly say that the primary purpose of conventional legal scholarship is to generate usable solutions to problems that exist within the legal arena"; lawyers will therefore be reluctant to consult disciplines that do not "offer the kinds of determinate, exclusive answer that the business of "deciding' requires").

88. For a summary of the critiques of republican historiography, see Nomi Maya Stolzenberg, A Book of Laughter and Forgetting: Kalman's "Strange Career" and the Marketing of Civic Republicanism, 111 HARV. L. REv. 1025, 1027-39 (1998) (book review).

89. Sometimes a title says it all. See, e.g., Collier, supra note 10 (The Use and Abuse of Humanistic Theory in Law...); Nussbaum, supra note 10 (The Use and Abuse of Philosophy in Legal Education).

90. See, e.g., Flaherty, supra note 10 , at $551-55$; Leiter, supra note 83 , at 80.

91. Mark Tushnet, Interdisciplinary Legal Scholarship: The Case of History-in-Law, 71 CHI.KENT L. REV. 909, 914 (1996); see, e.g., Charles W. Collier, Interdisciplinary Legal Scholarship in Search of a Paradigm, 42 DUKE L.J 840, 852 (1993).

92. See Tushnet, supra note 91 , at $934-35$ ("Law-office history is a legal practice, not a historical one. The criteria for evaluating it, for determining what is a successful performance, must be drawn from legal practice rather than from historical practice. I believe the same conclusion can be drawn about interdisciplinary legal scholarship generally." (emphasis added)).

93. See G. Edward White, Reflections on the "Republican Revival": Interdisciplinary Scholarship in the Legal Academy, 6 YALE J.L. \& HUMAN. 1, 28-29 (1994).

94. See STANLEy FISH, THERE'S No SuCH THING AS FREE SPEECH, and IT'S a GOOD THING, TOO 237 (1994). 
"for itself" 95 or by reference to "aesthetic" criteria. ${ }^{96}$ On the whole, however, discussions of the relation of law to literature seem remarkably disconnected from the larger debate about interdisciplinarity in law.

This disconnection is somewhat ironic because the law-and-literature endeavor is typical of other "law ands" in its remarkable lack of selfconsciousness about the use of the term "law," especially as that term is contrasted to the equally un-self-consciously employed term "literature" ("history," "philosophy," etc.). One example of this phenomenon is the argument, made as part of the moral uplift project of humanist law-and-lit, that literature is a source of values otherwise missing from the law. ${ }^{97}$ This argument rests on a vision of law as inherently empty or ignorant of moral values-values that must be supplied from "outside" of law. This vision is sustained by the initial story of law's development, in which law distinguished itself as a profession by excluding literary and philosophical concerns; once law was conceptualized as analytical, scientific and practical, the literary and philosophical concerns that were once part of law could only reappear if they were yanked back "in." 98 This same vision of law-as-barren-science recurs in frequent contrasts between dry, technical,

95. C.R.B. Dunlop, Literature Studies in Law Schools, 3 CARDOzo STUD. L. \& LITERATURE 63, 93-95 (1991).

96. POSNER, supra note 13, at 306, 329; see also Miller, supra note 11, at 261 (questioning whether James Boyd White's use of fields of law and literature is "undisciplined").

97. See supra text accompanying notes 17-20; see also Heald, supra note 44, at 3-4 ("Legal language often obscures the value-laden nature of legal choices. In fact, law talk is seldom concerned with overtly separating good from bad." But "fiction is an undeniably rich collection of studies in the appropriateness of human action." Thus, literature "may be a unique repository for information capable of enriching legal decision making."); Hirshman, supra note 16, at 179 ("Since... judging involves and will continue to involve judgements based on moral principles, how can society generally, and educators in particular, produce judges of the appropriate moral character and habits of mind to formulate such principles? The answer, I suggest, is implicit in the return of law to the humanities after its long and uneasy sojourn in the realm of science....").

98. See William H. Page, The Place of Law and Literature, 39 VAND. L. REV. 391, 415 (1986) (book review) ("The modern field of law and literature is, paradoxically, a product of the breakdown of the configuration of law and literature. When law and literature were considered coordinate disciplines, united by their consonance with universal principles . . . by definition there was no need for an interdisciplinary field of study."). I by no means wish to suggest that the story of law's development as a separate, nonliterary discipline is false. See supra note 76. Nor do I mean to suggest that there is, somewhere, an account of the development of law in the United States that is not a story. See Baron \& Epstein, supra note 64, at 171-73 (describing the position that all arguments and accounts proceed from some nonneutral framework and, in this sense, are all "stories"). In employing the professionalization story described in the text, law-and-lits justifiably relied on the best available historical accounts of the rise of law as a professionaccounts that have not, to my knowledge, been seriously challenged.

On the other hand, there is no denying the professionalization story's utility in demonstrating the need for an "and" to supplement law. Moreover, law-and-lits have tended to present and utilize the professionalization story in a rather flat and simplified way that emphasizes what was lost when law separated from the humanities in the 19th century. The more unliterary, unphilosophical, and technical the law is understood to be, the more sense it makes to reach out toward the moderating and enriching resources of non-law disciplines such as literature. 
rule-governed law and nuanced, emotional, complex literature. ${ }^{99}$ Such contrasts rely on-even as they entrench-a fairly conventional vision of law as a domain empty of anything other than rules, inhabited solely by unimaginative rule technicians. ${ }^{100}$

These characterizations have, of course, been questioned. It has been noted, for example, that there are plenty of emotions, values, and general human messiness already within the law, as any sensitive reading of the facts of cases proves. ${ }^{101}$ Robert Weisberg has made this point eloquently:

It is obviously desirable that law should be informed by the voice of the concrete, the particular, the empathetic, the passionate. But to make this point about legal discourse hardly should require recurrence to the great works of the Humanities.... Lawyers or law students are or should be perfectly aware even from conventional case analysis that human pain underlies doctrinal abstraction, that the general rules of common law doctrine live in tension with and are often undone by the particular stories of parties to the case. ${ }^{102}$

Critiques like Weisberg's suggest that the contrasts between law and literature are complex, but they do not suggest that there are no meaningful contrasts. More importantly, they do not articulate explicitly-beyond assertions that law can be moral, sensitive to values, and so forth-what understanding of law should be used in drawing the contrasts.

Things are not much better on the hermeneutic or narrative side. The suggestions that law is like literature in being textual, or that law is inherently narrative in structure or content, seemed to auger a reconsideration of the divisions between the disciplines. The promised reconsideration, however, has often been rather thin. On the hermeneutic side, the law-and-literature categories reasserted themselves most visibly in

99. See, e.g., Elliott M. Abramson, Law, Humanities and the Hinterlands, 30 J. LEGAL EDUC. 27,29 (1979) (stating that "[p]rofessional training narrows by omitting," but "the humanities can broaden and free"); Dunlop, supra note 95, at 64 ("Fiction gives legal scholars the opportunity to get beyond the technical and circumscribed study of legal rules ....").

100. On the construction of law as a place filled almost entirely by rules, see Baron, supra note 10 (manuscript at 3-4). As I explain below, the boundaries of this domain are in no sense natural or "real," and, indeed, they may be constructed by the very contrasts that are offered for purposes of challenging them. See infra text accompanying note 116.

101. See, e.g., Robert Weisberg, Proclaiming Trials as Narratives: Premises and Pretenses, in LAW'S STORIES, supra note 25, at 61,70-71 ("To say that we need to read works of imaginative literature to see [that human pain underlies doctrinal abstraction] is odd. ... [N] ormal human minds and sensibilities should realize the point even by reading the bare facts of the case....").

102. Robert Weisberg, The Law-Literature Enterprise, 1 YALE J.L. \& HUMAN. 1, 17-18 (1988). Moreover, as noted earlier, many have questioned whether literature is truly a reliable moral corrective, assuming one is needed. See, e.g., Morawetz, supra note 11, at 518 ("Those who create literature, no more and no less than those who write legal texts as judges or legislators, have conflicting ethical insights and occasionally none at all."). 
debates over whether law's textuality is different from literature's, especially insofar as - as many have argued-interpretations of legal texts invoke coercive state power, while interpretations of literary texts do not. ${ }^{103}$ On the narrative side, claims that law is itself a narrative coexist with claims that law is not narrative enough; that stories, which employ the particular, the emotional, the human, are needed to counteract the abstraction and pseudo-objectivity of law. ${ }^{104}$ The latter claims reinscribe a divide between storytelling and legal analysis, with the former correcting and, in the eyes of some, challenging the latter. ${ }^{105}$

The specifics of these claims, like the claims of humanist law-and-lit, have been disputed. Some have argued that interpretation outside legal settings also involves the imposition of significant coercive power and so is similar to interpretation in law, ${ }^{106}$ while others, continuing to insist that legal interpretation is coercive in a way that literary interpretation is not, have downplayed the importance of that distinction. ${ }^{107}$ Critics of narrative law and literature have questioned "the premise that narrative concreteness by itself is some sort of guarantee of intellectual integrity or moral virtue," ${ }^{108}$ and also whether, even if it is, particularity alone is capable of transforming law..$^{109}$ Again, these critiques suggest that contrasts between the textuality or narrativity of law and literature should not be drawn simplistically, but they do not suggest that there are no useful contrasts. And again, they largely leave unexamined how "law" should be defined in drawing those contrasts.

The less anyone discusses what "law" is for purposes of comparing law to literature, the easier it is to think of law in fairly stereotypical terms drawn from the standard story about law's development as an independent, nonhumanistic discipline. As depicted by the stereotype, law is instrumental, analytic, rational, nonemotional, technical, mechanical, and-

103. See, e.g., POSNER, supra note 13, at 236 ("A poet tries to create a work of art, a thing of beauty and pleasure.... A legislature is trying to give commands ...."); Cover, supra note 62, at 1601 ("[L]egal interpretation takes place in a field of pain and death."); see also supra note 62 and accompanying text (describing the different stakes involved in literary and legal interpretation).

104. For a summary of these themes of the legal storytelling movement, see Jane B. Baron, Resistance to Stories, 67 S. CAL. L. REV. 255, 267-69 (1994); and Jane B. Baron, The Many Promises of Storytelling in Law, 23 RUTGERs L.J. 79, 86-92 (1991) (book review).

105. [S]tories disrupt ... rationalizing, generalizing modes of analysis with a reminder of human beings and their feelings, quirky developments, and textured vitality....I suggest ... that the revival of stories in law is welcome, not as a replacement of legal doctrine, economic analysis, or philosophic theory but as a healthy disruption and challenge to them.

Martha Minow, Stories in Law, in LAW's STORIES, supra note 25, at 24, 36:

106. See, e.g., Sanford Levinson \& J.M. Balkin, Law, Music, and Other Performing Arts, 139

U. PA. L. REV. 1597, 1626-27 (1991).

107. See, e.g., WEST, supra note 9 , at 203.

108. Weisberg, supra note 39 , at 1107-08.

109. See Baron \& Epstein, supra note 64, at 181-83. 
above all-doctrinal. It is a technological science or craft, a science perhaps not as completely autonomous as Langdell suggested at the end of the nineteenth century, but relatively autonomous nonetheless. ${ }^{110}$

This depiction of law as autonomous paradoxically reappears even in approaches that, instead of contrasting law to literature, treat law as a form of literature. This is most famously the approach of James Boyd White, who has argued that "the life of the law is ... a life of art, the art of making meaning in language with others." 111 The "central concern" of this life, White argues, is "the kind of relations that we establish with our inherited culture and with each other when we speak its language." ${ }^{112}$ Poetry, philosophy, and law are but specific instances of the general "cultural and ethical activity of making meaning in relation to others." 113

This view of law as literary ${ }^{114}$ in character simply renders law autonomous in a different way. Law does not require supplementation by anything "outside" of itself, because-given the level of abstraction at which the process of doing law is described-nearly everything that could be outside is actually already "inside" law. Law, though broadened, remains a self-enclosed discipline. Indeed, the broader and more "integrated" "115 law is, the less problematic its self-enclosure comes to seem.

The tendency in these analyses to treat law as autonomous makes it difficult to assess the possibilities for connecting law with other disciplines. Assessing connections requires understanding what lies on either side of the "and" bridge, but this is precisely the terrain that is not being carefully mapped. We cannot determine the significance of literature for law if we uncritically define literature as simply everything law is not, ${ }^{116}$ and the same is true if-as seems to be the case-the law-and-literature enterprise

110. On Langdell's vision of law's autonomy, see sources cited supra note 77. If law-and-lits truly believed law to be inherently dehumanized or morally dessicated, there would be no point in calling for the enriching supplementation of literature. Logically, then, the law-and-lits would seem to be arguing not that law is necessarily autonomous, only that it has (for contingent historical reasons) become an entity of which Langdell would very much approve. On the other hand, the "law" to which "literature" is contrasted is never the more humanized, moral, emotionally sensitive institution it is apparently capable of becoming. For comparative and rhetorical purposes, "law" becomes mere rules. As I suggest below, the more law is described in doctrinalist terms, the harder it may be to (re)envision or (re)create it as anything else. See infra text accompanying note 121 ,

111. WHITE, HERACLES' Bow, supra note 4 , at xii.

112. WHITE, WORDS, supra note 4, at 273.

113. Id. at 275 .

114. See id. at 283.

115. White emphasizes the importance of "the integration of parts of our culture, and parts of ourselves, into new wholes." WHITE, JUSTICE AS TRANSLATION, supra note 82, at 21.

116. See J.M. Balkin, The Domestication of Law and Literature, 14 LAW \& SoC. INQUIRY 787, 799 (1989) (book review) (critiquing Posner's analysis of law and literature on precisely this ground). 
continues to describe law as either everything literature is not or everything literature already is.

I do not mean to call here for a new or different set of boundaries; quite the contrary. Fruitful exploration of interdisciplinarity in law and literature does not require the delineation of the "true" and "real" boundaries between law and literature. It cannot, for precisely the reason that "law" and "literature" are not natural categories describing disciplines that are just there, preexisting and predefined. Our understanding of the categories may be as much a product of our attempts to compare and contrast them as of any quality that they have apart from the context of those contrasts. And the interesting question is not whether any particular definition of the categories is true, but what it might tell us about our aspirations for law and for the place of law in our culture.

It is in this light that the curious reaffirmance of law's autonomy seems most significant. Locating emotion and empathy outside law and inside literature, as so much humanist law and literature has done, suggests an unacknowledged investment in exactly that vision of cold, mechanical, dehumanized law that literature is supposed to combat. Similarly, locating interpretive power inside law and outside literature, as so much hermeneutic law and literature has done, suggests an attachment to exactly that vision of law as uniquely authoritative that attention to textuality is meant to put in question. These investments and attachments are of great cultural interest because they implicate questions of what we want or can envision law to be, of how we see the role of law as distinct-and we seem to want it to be distinct-from other social institutions. But these questions are, alas, not the ones the law-and-literature enterprise has considered.

In summary, what has kept law and literature, and "law and" more generally, from having the impact that they otherwise might have had in the legal academy has been insufficient thoughtfulness about interdisciplinarity. Like other "law ands," the law-and-literature enterprise purports to connect two disciplinary domains, but it has not questioned how those domains are defined and bounded. It has thus missed opportunities to raise and address important questions that would seem central to the "law and" project, that is, questions about how we distinguish "legal" from other sorts of knowledge and about our cultural investment in viewing law as an autonomous discipline.

\section{B. Law, Literature, and Lawyers}

Law and literature may not in fact be significantly interdisciplinary in the senses I have explained. But to practicing lawyers, law and literature appears all too interdisciplinary in the sense of being law admixed with something else that is clearly not law. If law is autonomous in the ways in 
which law-and-literature scholars inadvertently suggest, that is, if practicing law consists of the dry and technical manipulation of rules, then of what relevance is literature (or anything else) to lawyers?

American lawyers' enchantment with doctrine is evident on many fronts. It is a prominent theme in recent debates over whether the legal academy has lost touch with and become irrelevant to the real world of practice. In these debates, the world of practice is almost always defined as the world of doctrine. ${ }^{117}$ Further evidence of the profession's fixation on rules comes from law-and-society scholars, who have tried to assess why empiricism has made so little headway in American legal education. These scholars have concluded that the answer lies in the extent to which lawyers and even law professors see "the main business of doing law" as "doing rules." 118

There are some noteworthy ironies to practitioners' views of law and literature as irrelevant. From the start, proponents of law and literature have argued that literature is important precisely because its lessons are practical. As early as 1908, for example, Wigmore argued that lawyers should read legal novels because "the lawyer must know human nature." And, Wigmore asserted, "for this learning ... he must go to fiction, which is the gallery of life's portraits." 119

Narrative law-and-lits have argued for storytelling in similarly instrumental terms. Lawyers must persuade, the narrativists point out, and one of the most effective forms of persuasion is storytelling; therefore, they argue, effective lawyers must learn to be effective tellers of tales. ${ }^{120}$ Finally, the theories offered by hermeneutic law-and-lits can be seen as useful "strategies" for a task lawyers are regularly called upon to perform: the interpretation of writings such as statutes and documents. ${ }^{121}$

117. See Edwards, supra note 1 , at $42-57$ (criticizing the legal academy as insufficiently attentive to and respectful of doctrine). Judge Edwards' article provoked a raft of responses. See, e.g., Symposium: Legal Education, 91 MrCH. L. REv. 1921 (1993). The persistent fascination with this issue (and with citation counting) is reflected in Michael J. Saks et al., Is There a Growing Gap Among Law, Law Practice, and Legal Scholarship?: A Systematic Comparison of Law Review Articles One Generation Apart, 30 SUFFOLK U. L. REV. 353 (1996).

118. JOHN HENRY SCHLEGEL, AMERICAN LEGAL REALISM AND EMPIRICAL SOCIAL SCIENCE 255 (1995); see also Lawrence M. Friedman, The Law and Society Movement, 38 STAN. L. REV. 763, 774-75 (1986) (arguing that the law-and-society movement has not caught on in American law schools because it stresses what is happening in society, whereas lawyers are interested only in what is "inside" the legal system).

119. Wigmore, supra note 4, at 579. This sentiment is by no means outdated. See Hirshman, supra note 16, at 198 ("Legal education should harvest literature ... for literature's insights into the human condition.").

120. See, e.g., Richard Delgado, Storytelling for Oppositionists and Others: A Plea for Narrative, 87 MiCH. L. REV. 2411, 2429-31 (1989) (describing some of the conditions necessary for stories to persuade effectively); Lopez, supra note 25, at 2-3 (arguing that lawyering means problem-solving; that problem-solving can involve trying to persuade others to do what we want them to do; and that "[t]o solve a problem through persuasion of another, we therefore must understand and manipulate the stock stories the other person uses").

121. See, e.g., Abraham, supra note 22, at $115,126$. 
Why is it that lawyers do not believe that these very practical aspects of literature relate to what they do? One possibility is that lawyers and lawand-lits are talking past each other, failing to engage on the issue of what "practical" lawyering is. This problem connects to a second irony, which is that law-and-literature scholarship may reinforce lawyers' narrow vision of practice as rules even as it seeks to challenge and expand that vision. Although the law-and-literature enterprise laments the dry doctrinalism of law, it repeatedly depicts currently practiced law as basically the application of rules. Such depictions, again parasitic on the standard story of the rise of law as an independent discipline, may actually help construct exactly the doctrinalist practices they are meant to disrupt. Cause and effect here is obviously complicated, but it may be that lawyers can only be told a certain number of times that what they are doing, however misguidedly, is mechanically applying rules before they come to believe that applying rules is essential to the practice of law. Indeed, the more lawyers adopt this view, the more difficult it may be to convince them that there is "practical" value to anything else.

\section{CONCLUSION: “LAW AND” INSIDE OUT}

What is "inside" law and what is "outside"? This is an essential question for all "law and" endeavors, for it is only what law does not already include that needs to be added. The idea of "law and" almost requires "law and" scholars generally, and law-and-literature scholars particularly, to treat law as a bounded entity, an independent domain. It is only if there is a divide between law and other disciplines that law can be connected to those disciplines through some sort of "and" relationship. Thus, the independence of law from other disciplines is what creates the possibility of interdisciplinarity.

The possibility of an "and" bridge between law and other disciplines has been, to some, a source of great hope. Each "law and" movement holds out a promise to bring new light to bear on old legal questions in ways that will, the claims variously assert, promote social justice, force a rethinking of objectivity, humanize legal practitioners, add moral or historical dimensions to jurisprudence, and so forth. Law and literature, in all its diverse and perhaps inconsistent strands, is no exception. Literature and literary methods will, it has been argued, enrich, instruct, enlighten, and correct law.

But what is this "law" entity that literature will supplement? In a move characteristic of "law and" work, much law-and-literature scholarship elides this question altogether, relying sometimes tacitly and sometimes explicitly on a standard story of how law developed as a distinct and expert 
profession. In this story, law distinguished itself by discarding its humanist, literary element, leaving a domain consisting almost entirely of rules.

And here is a final irony. For much of the American legal academy, this domain is functionally empty. Many have grown skeptical of legal doctrine's capacity to solve legal problems in a convincing way. ${ }^{122}$ Arguments about legal rules have been shown to fall into predictable patterns, with rule encountering counterrule or exception, policy encountering competing policy, text encountering legislative history, and so forth. ${ }^{123}$ The rules are "in" there, all right, but they do not seem to be doing much to determine the outcome of cases.

If law's territory is a desert, the "law ands" can pour no end of water on it, but little will bloom. There is not much hope for interdisciplinarity and all that it promises if one of the disciplines is just not there. Like the proponents of other "law ands," the law-and-lits have a remarkable interest, then, in finding some substance in law, in law being a separate discipline that literature (or some other discipline that is not itself law) can somehow enlighten.

I do not in fact mean to suggest that the field "law" was created or constructed entirely by the needs of the "law and" endeavor-although I realize that what I have said could be interpreted in that manner. On the other hand, I do not believe law has determinate boundaries that comparisons with literature (or history or philosophy or economics) neutrally discover. I believe that the definition of the field "law," like that of any other field, will to some degree reflect or be a product of what we, as a culture, want law to be and do. ${ }^{124}$ The greatest promise of "law and" lies in exploring these cultural aspirations, but it cannot deliver on this promise if it takes law's boundaries for granted.

122. While this position is today associated with Critical Legal Studies, it originated with the legal realists. See Felix S. Cohen, Transcendental Nonsense and the Functional Approach, 35 Colum. L. REV. 809, 820-21 (1935). On Critical Legal Studies, see MARK KeLMAN, A GUIDE TO CRITICAL LEGAL STUDIES (1987); and Joseph William Singer, The Player and the Cards: Nihilism and Legal Theory, 94 YALE L.J. 1 (1984).

123. See, e.g., James Boyle, The Anatomy of a Torts Class, 34 AM. U. L. REV. 1003, 1051-60 (1985); Laura E. Little, Characterization and Legal Discourse, 46 J. LEGAL EDUC. 372, 383-92 (1996); Jeremy Paul, The Politics of Legal Semiotics, 69 TEX. L. REV. 1779, 1786 (1991).

124. Cf. Guyora Binder and Robert Weisberg, Cultural Criticism of Law, 49 STAN. L. REv. 1149,1152 (1997) (suggesting a similar conception of law). 
